\title{
APPLYNG THE PRINCIPLES OF CORPORATE GOVERNANCE IN CENTRAL AND EASTERN EUROPEAN COUNTRIES, THE NATIONAL CHARACTERISTICS AND PARTICULARITIES OF CORPORATE GOVERNING IN THE ROMANIAN ECONOMY
}

\author{
Zapodeanu Daniela \\ Kolozsi Lucia ${ }^{2}$ \\ Durgheu Liliana ${ }^{3}$
}

\begin{abstract}
With direct support of the OECD and the World Bank the East-Central European states have been encouraged to adopt and implement codes of conduct and corporate governance principles to minimize risk, boost performance, improve business access on stock markets, strengthening the market position of firms, professional management, demonstrating transparency and social responsibility.
\end{abstract}

Key words: corporate governance, governance principles, stakeholders, Romanian companies

JEL codes: $G 38$

\section{Introduction}

The political changes of the 1990 in central and eastern European countries have marked the beginning of difficult structural reforms in an economic area where there were no shareholders and capital markets, the state acting as sole owner under a command economy incompatible with the competitive environment. For corporate governance to be relevant two basic measures needed to be implemented: the privatization of former state enterprises and building an appropriate institutional infrastructure for ensuring financial discipline in a highly vulnerable business environment. The privatization process has been the mainstay of structural reforms in Central and Eastern European countries and experienced different rates between these countries. Thus, in Poland in the period 1990-1992, over 80\% of state enterprises were privatized, and in Hungary 59\%, in countries like the Czech Republic and Bulgaria, most privatizations have been carried out in 1990-1995, while privatization in Romania did not start until 1992.

After 2002 corporate governance began to be regarded as an objective measure necessary to de-politicize decision-making, to protect minority shareholders and to stop the destruction of companies' property after the closing process of mass privatization. The main function of the management of a company being to promote corporate interests so the main task consisting in maximizing shareholder value.

Currently, OECD and World Bank are the main entities involved in addressing the stage of implementation and applicability of the principles of corporate governance codes of conduct in the field. In 2004 OECD has outlined and published reference levels of indicators that upon analyzing, processing and interpretation evidence show the implementation or not of the principles of corporate governance. These indicators are important for investors, policy makers, stakeholders groups, the corporations that take care of their value prove the existence of a strong system of governance.

In 2006, the World Bank released the results of a study based on impressive research efforts,

\footnotetext{
${ }^{1}$ University of Oradea, Faculty of Economics, danizapodeanu@ yahoo.com

${ }^{2}$ The Chamber of Auditors, Bihor, luciakolozsi@yahoo.com.

${ }^{3}$ The Chamber of Auditors, Bihor, lilianadurgheu@yahoo.com
} 
which have stretched from 2001 to 2006 in 17 transition countries. The study examines changes in corporate governance practices assessing how to comply with its principles, namely those concerning the protection of shareholders, fair treatment for all shareholders, the role of stakeholders, respecting the principles of information and transparency, and also the accountability of the Administration Council.

For each principle were applied evaluation factors from 1 (lowest) to Level 5 (best), as follows: O (Observed)- 5 points; LO (Largely Observed) - 4 points; PO (Partially Observed) - 3 points; MNO (Materially Not Observed) - 2 points; NO (Not Observed) - 1 point.

Based on public data provided by the World Bank, Mihaela Onofrei (Onofrei M., 2009) performed an analysis of the implementation of each principle, synthesized the most important of them. The study presents the analysis of the principles of corporate governance in 11 Central and Eastern European countries, of which nine new member of the European Union (Bulgaria, Czech Republic, Hungary, Lithuania, Latvia, Poland, Romania, Slovakia, Slovenia) and two states of the former Yugoslavia (Croatia and Bosnia-Herzegovina). In the analysis performed (Onofrei M., 2009) the starting point was to analyze the implementation of each principle.

The implementation of the principle for shareholder-rights protection -the most important principle- is verified by the shareholder involvement in decision making, voting rights, the acquisition or loss of control over the corporation through the capital market. After processing the data recorded the best qualifying country is Poland, while our country gets only 3 points thanks PO qualifier (McGee R., 2008). In terms of shareholder involvement in decision making and the exercise of voting rights (as representative factors impacting on principle), the study reveals that in general, shareholders are involved in decision-making process, Hungary was the only one who receives maximum score for this indicator, also shareholders exercise their right to vote " to a large extent", Lithuania receives the maximum score. Romania has a relatively constant position, a medium level, and its rating is "Largely Observed". With regard to capital structure and distribution control, the study concludes that there is no risk of hostile takeovers in companies from 11 analyzed countries, given that financing through the stock exchange is not significant, because capital markets in this area are still emerging markets.

Fair treatment of all shareholders is a principle with important role in creating an atmosphere of mutual understanding among the shareholders due to their equal treatment, preventing potential conflicts between majority and minority shareholders. The analysis was performed on two major factors, namely the protection of minority shareholders against the abuse of major-shareholders and distribution of documents and materials of interest to all shareholders, it shows a much better protection of minority shareholders to the distribution of documents and materials of interest to all shareholders. For the protection of minority shareholders against controlling shareholders abuse, eight countries from those analyzed receive the mark LO, e.g. 4 points for each country. In connection with the second factor, the distribution of results is carried out on four levels of assessment, it is found that four countries (Latvia, Lithuania, Slovakia, Croatia) receive 4 points and the rate LO, four countries (Romania, Poland, Slovenia, Hungary) 3 points and grade given is PO, in the case of Bulgaria it is used for the first time the NO grade and in case of Czech Republic the indicator is accomplished in a small extent. The stakeholders categories have the right to be informed about the enterprise activity and their results, also their interests must be protected based on corporate social responsibility. The analysis of this principle has started issuing its recognition by corporate governance systems of the 11 states, taking into account two representative factors which contribute to good implementation of the principle: the opportunities for the efficient resolution of complaints of stakeholders and enhancing group performance mechanisms for active participation of stakeholders in decision making. The analysis showed that the role of stakeholders groups is widely recognized in 9 of the 11 countries analyzed, except Bulgaria and the Czech Republic, where there is a low performance of that principle. Regarding the main factors affecting the smooth implementation of the principle it is established that complaints 
made by stakeholders are resolved extensively in Latvia, Lithuania, Romania, Slovenia, Slovakia, Hungary, Bosnia and Herzegovina, and the mechanisms of active participation of stakeholders in decision-making have allowed better implementation of the principle in the analyzed states. It also points out that on the first factor, our country gets a good result, while the second level of implementation is low, because interest groups (stakeholders) is little known in corporate governance culture in our country. In Romania we meet two categories of interest groups whose interests are taken into account in decision making: the employees and creditors. However, none of them is systematically treated by the Board of Directors as a legitimate interest group.

\section{Implementing corporate governance principles in Eastern Europe}

Implementing the principle of information and transparency is the responsibility of corporate management, which is responsible both for the quality of information available to interested parties as well as how to collaborate with internal and external auditors. The World Bank study starts from the needs for information in a timely and fair manner to all stakeholders, analyzing the standards for disseminating and auditing information. The results of analyze suggest how it is implemented this principle and have led to the conclusion that states have some problems in the issues of transparency and access to information, the best ratio recorded is only "partially observed". Also, the two states of the former Yugoslavia and Slovakia were rated as "observed in a small way". Implementing the principle in action is conditioned by several factors, most important being the audit independence and honesty, punctuality and cost effective access to information. According to data presented in the study review, audit independence appears to be the biggest problem - no state has a maximum rating, the best being "Partially observed" ( 7 cases). Romania has a low grade, "noted in small extent" this also being the case for Lithuania and Croatia too. The second factor does not create problems, since there are two countries (Hungary, Poland) receiving top ratings. Also, there is a uniform distribution, with 4 states, both rated "Observed in a large extent", as well as a "Partially observed" (among which Romania).

The Board of Directors is the cornerstone of corporate governance system and its role is to control and supervision of managers. Regarding the responsibility of the Board, the data survey shows that the Board fulfills in part, in a limited duty the principle of acting in a responsible and careful manner. Implementing the action is conditional on several factors, which may indicate compliance with the law, the full realization of the functions and independence of directors to managers. Analysis of these factors showed a contradictory situation, on one hand largely according to the law on the other hand the board does not completely fulfill its functions. This means that its action is highly formal, that there are regulations, but they are not applied in practice. Regarding the independence of the managers, there is limited and even reduced, the independence of the Board is seriously questionable if one takes into account the fact that in four cases (among which Romania) we have found the "Observed in a lesser extent" rating. Prevailing verdict is "Partially observed"(5 states) and supports the formal statement of the board acting as stated above. Following tabulation and processing of the points adjectives, we obtain a ranking for the 11 countries analyzed, Table 1.

Table no. 1.

Situation of implementing corporate governance principles (aggregate score)

\begin{tabular}{|l|l|l|l|l|l|l|l|l|}
\hline No. & Country & P I & P II & P III & P IV & P V & Total & Rank \\
\hline 1. & Bulgaria & 4 & 4 & 3 & 3 & 2 & 16 & V \\
\hline 2. & Czech & 4 & 3 & 2 & 3 & 3 & 15 & VI \\
\hline 3. & Letonia & 4 & 4 & 4 & 4 & 3 & 19 & II \\
\hline 4. & Lithuania & 4 & 4 & 4 & 3 & 4 & 19 & II \\
\hline 5. & Romania & 3 & 3 & 4 & 3 & 3 & 16 & V \\
\hline 6. & Poland & 5 & 4 & 5 & 4 & 4 & 22 & I \\
\hline 7. & Slovakia & 3 & 4 & 4 & 2 & 3 & 16 & V \\
\hline
\end{tabular}




\begin{tabular}{|l|l|l|l|l|l|l|l|l|}
\hline 8. & Slovenia & 4 & 4 & 4 & 3 & 4 & 19 & II \\
\hline 9. & Hungary & 3 & 4 & 4 & 4 & 3 & 18 & III \\
\hline 10. & Croatia & 4 & 3 & 4 & 2 & 4 & 17 & IV \\
\hline 11. & Bosnia and Herzegovina & 4 & 3 & 4 & 2 & 2 & 15 & VI \\
\hline
\end{tabular}

Source: Mihaela Onofrei, Corporate Financial Governance

Centralized data leads to a hierarchy with six levels, from the highest score, 22 points (Poland), to the lowest- 15 points (Bosnia and Herzegovina). Romania, under the circumstances, is in 5th place with 16 points, tied with Slovakia and Bulgaria.

The privatization process in Romania has highlighted the needs for implementing corporate governance rules, for at least two reasons, improving property management practices of companies privatized and transfer of control of political bodies to specialized administrative councils. When setting up companies resulting from the transformation of former state enterprises, the state gave up the goods as a contribution to the capital of these companies.

The privatization process in Romania was confronted with a number of difficulties related to economic constraints, including lack of domestic capital as being the most acute, technical constraints related to lack of experience or lack of accounting rules and institutional abuse matters. In this respect, one of the major problems was the lack of autonomy of the new company transformed from AVAS, former SOF (State Ownership Fund). The fact that the general meeting of shareholders in these companies is made up of representatives of AVAS deepens the dependence on the State, amputates the divisions autonomy, increases the degree of centralization and obedience. Abuse of the state as a shareholder was regulated by law, because by Article 21 of Company Law No. 31/1990 has established the rule that the state was the sole shareholder until partial or full privatization of the company concerned, the general meeting being excluded (Piperea Gh., 2005). In this context, the powers were exercised by the council of the General Assembly empowered the state to start the privatization process.

After the onset of the first privatization law (Law no.58/1991), the empowered state board has been replaced by the General Assembly of Shareholders (GMS) and the Board of Directors was established. The fact that members of both governing bodies were appointed and not elected by the State Property Fund, the Private Property Fund, created great confusion between the AGA and the Council. In addition, state-owned companies have many employees, so this social component becomes very important for the management, including the negotiating terms for a privatization contract.

In Central and Eastern European states, protection of employment in privatized companies has affected the privatization process in different ways. In the early years of privatization, the objective of preserving the initial level of employment was achieved indirectly by using the method of privatization MEBO (Management and Employees Buy-Out), which is a form of procurement which is taking over a company by managers and employees of that company, which guaranteed job security (derived from the dual role as an employee and owner). After MEBO transactions began to lose ground, the concern that privatized companies will generate significant unemployment began to be reflected in legal amendments introduced for this purpose in the privatization legislation.

Privatization contracts cannot reasonably include clauses on the situation of employees. In addition offering compensation for the compulsory redundant staff, but without clearly stipulating who bears the obligation to pay such compensation, is a political error generating inflation, but with a favorable impact on the electorate. In turn, the wages were the main instrument of negotiation between authorities and unions, often not correlated with wage labor productivity growth, left governments preferring to accept increases in wages without coverage on productive performance, all this is the price of remaining in power. Thus, transforming unions into a force to be reckoned, against diluting the authority of the Council and AGA, had negative effects on the financial discipline of state companies that have benefited from generous state aid to be kept in operation, 
even if they had loss and lack the necessary structural reforms.

In this context, implementing corporate governance rules was seen as a saving way to harmonize internal business requirements of a functioning market economy. In 2001, was adopted the corporate governance standards, the Code of Management and Administration, targeting publicly owned companies listed on Bucharest Stock Exchange. Market reaction was to reject rather than accept, given the content and the possible implications of the code. The code refers primarily to the minority shareholders, other investors are protected through periodic and continuous information, the principle of investor protection, specifying their rights (economic and nonproperty) and also their obligations (Piperea Gh., 2005). Its application has a narrow edge, as it is intended only for those companies that are in the PLUS category on Bucharest Stock Exchange, even if rules are binding. Thus, the issuer is required to include them in its constituent documents, otherwise he would be excluded from the trading category.

In terms of applicability of corporate governance standards, Romania has made important efforts, but the analysis presented in the previous paragraph placed it near the end of the ranking drawn up for the 11 states in 2006. On this occasion the World Bank had specific recommendations for each state examined. In the case of Romania they have launched two major themes of reflection: the need to increase the Board's role and the need for the introduction of specialized committees to advise the board, including accurate and timely preparation of financial statements. It was also recommended that at General Meetings of Shareholders of listed companies to take part external auditors to provide explanations for how the shareholders and the investment had honored their obligations under the privatization contract.

According to a study made by Applied Economics Group, based on a survey of Institute for Marketing and Polls (http:// www. Euractiv .ro/uniunea-europeana /articles \%7CdisplayArticle /articleID_10508/), in which 153 manufacturing firms took part, a representative sample based on the turnover, number of employees and regional distribution, published in the October edition of the Bulletin of Industrial Quarterly 29/05/2007, three quarters of companies states that do not know and apply the OECD corporate governance principles. The same document shows that $77.8 \%$ of the companies are not aware of corporate governance principles $(15.7 \%$ know them, and $6.5 \%$ do not know / no answer), while $79.7 \%$ of firms states that they do not apply these principles. Applied Economics Group Experts say it is possible that several firms are applying these principles, but not knowing that, given that only $34.7 \%$ of companies do not have a written code of conduct to establish formal rights and responsibilities of members of the Applied Economics Group and management, mean of communication and reporting between managers and shareholders, $\mathrm{t} 31.3 \%$ of companies shareholders do not receive in advance the documents that will be discussed at general meetings of shareholders, and $26.2 \%$, minority shareholders do not have access to accounting books. 30.8\% of these companies had not published, until May 2007, a report on business activity in 2006, while $79.7 \%$ of firms have not changed the company's auditor in the last three years. It underlines the need to organize public debates to a better understanding and implementation of these principles in the Romanian business environment, possibly enforced by legal mechanisms.

To see the entire image on the business environment in Romania we show only a few aspects of Press Release of 31 October 2007, which includes the Global Competitiveness Report 2007-2008, released by the World Economic Forum, which places Romania on the 74 of 131 countries in drop a place to position 73 of the last report. Overall, the report concludes, Romania has stagnated in the Global Competitiveness Report 2007-2008. Among EU countries, Romania ranks 26 of 27, just ahead of Bulgaria. According to the report, Romania is placed on investing in category-based economies, where the determinants of competitiveness related to education, the level of internal competition, labor market, financial market, the technological training (capacity to absorb technologies) and market size. Romania has competitive disadvantages in particular as regarding: the transparency of government decisions (No. 126), the ethical behavior of firms (No. 103), the 
intensity of local competition (No. 82), the tax burden (No. 108) existence of next-generation technology (instead of 93), private R\&D expenditure (No. 89), the collaboration between academia and business (90th). The most important issues facing the business are the tax and fiscal legislation. Corruption, inadequate infrastructure and political instability are also among the major obstacles, while inflation is not as top priority.

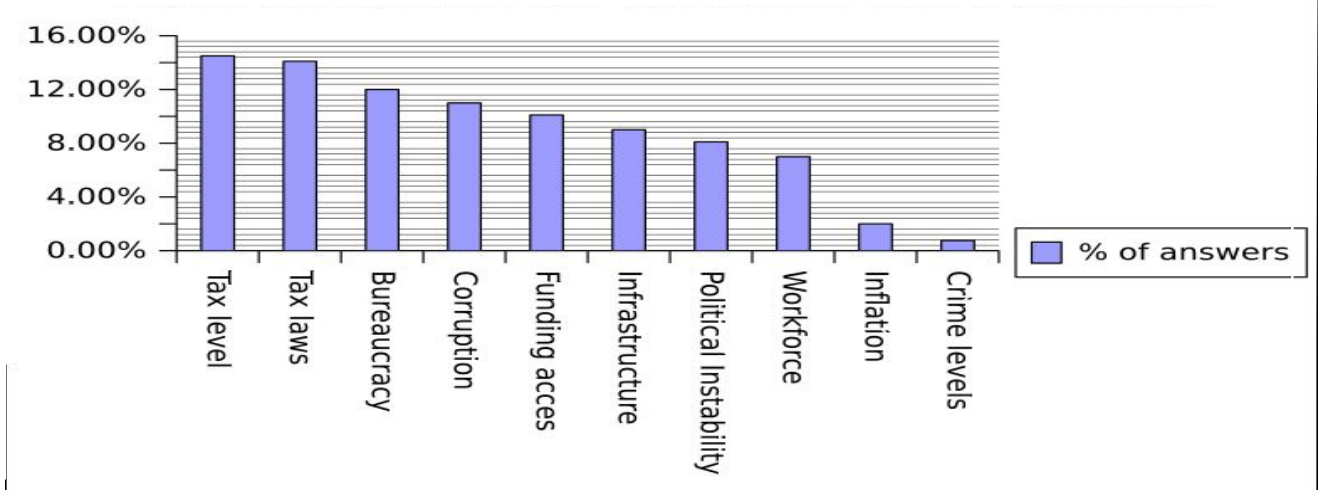

Fig. no. 1 Main obstacles in business

Source: www.Euractiv.ro/uniunea-europeana/articles\%7CdisplayArticle/articleID_10508/

One of the main aspects of corporate governance in Romania identified by the White Paper on Corporate Governance in South Eastern Europe are the weak institutional framework ard lack of priority in the implementation of existing laws, one of the most serious weaknesses is the of breach minority shareholder rights, which would require private sector take the lead in implementing and promoting public debate on corporate governance issues.

In Romania as in other countries of Central and South-East companies are characterized by the same general model based on corporate governance and internal control employees management, but certain features based on the condition of national economic, social, political, cultural specific forms of governance have emerged and developed. Corporate governance of Romanian enterprises can be analyzed and understood only through the development of the reform process in the context of transition from planned economy to market economy, a process which led to profound changes in the micro universe. To understand this phenomenon must mention the main methods of privatization that generated private sector training in Romania: MEBO mass privatization program and selling stakes to investors from outside companies. These processes have led to the formation of the following types of privatization of government enterprises:

State-owned companies or companies not fully privatized, the state is still a shareholder. Within these there is inevitably a conflict of interest between managers, employees and the state, resulting in contradictory objectives: maximizing profits, maintaining employment, tax revenues growth, political interests or individual satisfaction. Economic performance is the major objective of these economic entities, the interests of directors of these companies are rarely subordinated to the interests of shareholders.

Closed-private firms (small, medium or large), whose shares are not traded on an official market. Owners are usually managers, there isn't in this respect no conflict of interests between them. But there are many conflicts between partners who degenerates into civil litigation. Also managers do not seek to maximize the value of the company priority, but rather expanding the business.

- Companies privatized or opened, who knows a variety of forms, from those with a very dispersed shareholders whose rights are often neglected by those in which shareholders have a strong control over the enterprise. These conflicts occur between management companies and minority shareholders and between majority shareholder and minority shareholders. As with private 
firms closed, autonomous decision making and operational management team is high, organizational structures and information systems are flexible, dynamic and effective economic and financial levers used predominantly as a management tool.

It is thus evident from the presentation forms of existing companies that the main problem of corporate governance reform in Romania is made up of triple conflicts that arise between controlling shareholders and minority shareholders, which generates differences between management, the Board of Directors and minority shareholders and conflicts shareholders of the company's business partners, especially phenomena in transition economies, causing long term performance degradation for companies and even bankruptcy.

The structure of companies listed on BSE and RASDAQ have identified five major categories of investors: strategic investors, employees associations( Employees Associations), institutional investors, the state represented by AVAS (Authority for Privatization and Management of State Property) and individual investors.

The most common forms of violation of shareholder rights, according to studies by international institutions on capital market in Romania consists of dilution of minority shareholders property, transfer of profits outside the company, unfair allocation of profits or delay in providing dividends as well minority shareholders and limited access to information. A pertinent explanation for the creation of these cases were found in excessive authority in the controlling shareholders and the lack of control and a strong monitoring from other enterprise business partners. Due to the high degree of concentration of ownership, the company's governing bodies - Board of Directors, the directors and managers, are subordinate to the majority owner and consequently acts to satisfy the interests of that.

Romania occupies only 7 th place with a total score of 20.6 out of 36 maximum possible points from a sample of 10 countries like Greece, Israel, Hungary, Turkey, Poland, Russia and others, from a study conducted SG Equity Research for Emerging Markets [2000] on the efficiency and quality of governance relations between the firm and its social partners. Among the most important weaknesses of corporate governance in Romania revealed by this study are those related to unequal access to information for all shareholders, the prohibition of transactions for internal or majority shareholders, the role of the Board decreased access to other investors information media etc. Although the situation in Romania does not differ very much from the other countries examined, the most acute problem is regarding the enforcement of legal action regarding shareholders, within the meaning of real impossibility request their legal rights.

\section{Conclusions}

In conclusion, the Romanian companies traded on the stock market have resulted from either MEBO privatization process, mass privatization or sale of shares, which led to the formation of extremely desperate ownership, no activism in managing companies and, on the other hand, has triggered a strong majority or significant shareholders. These companies have opened a form of governance dominated by management and control of employees or controlling shareholders against minority shareholders'; interests and other social partners, which could generate with violation of minority shareholders and reduce their assets by controlling shareholders, Board of Directors and auditors having only a formal role, so the ineffective governance of companies had influenced in a negative way the economic outcomes and their ability to develop financial future by pursuing especially short-term employees and managers interests (and salary increases of allowances) with no interest in achieving stability and job security. Also failure of corporate governance principles reduces the pace of restructuring and corporate reorganization or bankruptcy of some firms postponing in financial difficulty. It can be find abusive situation's, like sales of assets of firms, or investment failure of modernization, maintenance or development of the productive potential of enterprises. Inefficient government takeover could lead to abuse of shares becoming more capital to shareholders, in terms of meeting the interests of major shareholders only 
by destructive methods of mitigation and transfer of wealth of minority shareholders, or the emergence of conflicts between shareholders and minority shareholders. You cannot apply in these circumstances, managers pay programs based on the actual value created, no promotion and incentive programs for staff on the criterion value, which can lead to excessive mobility of employees or to maintain an atmosphere strained as a result of conflict between management and / or employees. Distributions of situations may occur late or even non-delivery of shareholder dividends in order to provide incentives to employees and managers at the end. Other consequences arising from the inefficiency of corporate governance system can be linked to restrict trading of securities on the capital market, leading to increased volatility and risk of investment in these securities, or other inability of the active involvement of social partners, for eg. banks, the head of the company. Failure to comply with the principles of transparency of information, providing information and poor quality due to their lack of sufficient guarantees, can cause reduced access to bank loans or even loss of prestige of the firms listed on the market, or impossibility of making acquisitions or takeovers by other firms from the field in order to improve the activity of their respective owners.

Thus corporate governance system-listed companies determine the current economic and financial performance, but investor expectations regarding their future development opportunities. In these circumstances, on one hand how quality management and leadership is a key variable for assessing non-financial performance of companies listed on global stock market. On the other hand, capital markets functions through the redeployment of capital funding available and the most profitable investment, can significantly contribute to improving governance of listed companies and thus to improve their performance through mergers or acquisitions and active involvement of institutional investors in their management.

\section{References}

1. Anson, M., 2003. Corporate Governance Ratings: Come of Age, ICGN Conference, Amsterdam.

2. Mararu, A., 2007. The legislative powers of European Union http://www.business.adviser.Ro

3. McGee, R., 2008. Corporate Governance in Transition Economies, Springer Science, New York,

4. Onofrei, Mihaela, 2009. Corporate Financial Governance, Publishing House Wolterskluwer,

5. Piperea, Gh. 2005. Companies and stock market. Acquis comunitar, Publishing House All Beck, Bucureşti,

6. Robu, V., et all, 2004. Performance Analysis of Romanian companies listed on stock markets in the context of EU integration, Economic Review, Bucharest,

7. Vintilă, G. 2001. Theoretical aspects of corporate governance, Financial and monetary Colloquium ,Finance and economic dynamics, ASE.

8. Vasilescu, C., Corporate Governance in Romania, Scientific Conference Accounting and management information, Bucharest, A.S.E., 2002,

9. Commission Recommendation of 14 December 2004 fostering an appropriate regime for the remuneration of directors of listed companies, Official Journal of the European Union,

10. Report on the application by Member States of the EU of the Commission Recommendation on directors remuneration, 2007. Commission Staff Working Document, SEC 1022, Brussels,

11. OECD, 2004. Principles Of Corporate Governance -revised edition;

12. The World Bank 1998. The Business Environment and Corporate Governance

13. Ernst \& Young Romania, 2006. Newsletter:Accession to the EU

14. http:www.cis.org.htm

15. http://www.bvb.ro/info

16. http:www.Euractiv.ro/european-union 